\title{
Playing with Politeness in Economic Journals: The Strategy Used by Authors to Bring about Solidarity and Respect
}

\author{
Budianto Hamuddin $^{1}$, Dahler ${ }^{2}$ and Jeni Wardi ${ }^{3}$ \\ ${ }^{1}$ (Dept. of English Education, Universitas Lancang Kuning, Indonesia, budihamuddin@unilak.ac.id) \\ ${ }_{2}^{2}$ (Dept. of English Education, Universitas Lancang Kuning, Indonesia, dhlr_ikh@yahoo.com) \\ ${ }_{3}^{3}$ (Dept. of Economic \& Accountancy. Universitas Lancang Kuning Indonesia.wardi_jeni@yahoo.com)
}

\begin{abstract}
This study tries to analyse the dominance strategy of politeness used by authors in order to bring about solidarity and respect in selected economic journals. The corpus consists of 78.064 words from 12 different articles from one reputable Economic journal in United States namely the Economic Growth Journal (EG). The data were taken from six years latest where this study conducted in 2012. The conceptual framework of the present study based on the politeness theory by Brown and Levinson (1978) alongside the application onto scientific writing by Myers (1989) and persuasive tactics proposed by Mulholland (1994). This study calculated in total of 591 times the authors employ the tactics in order to maintain solidarity and respect in their articles. Positive politeness strategies seems to be the highest frequency (258 times) than the other 3 strategies. The data also reveals that EG authors have used 8 tactics in this strategy and it seems the 3 most used tactics was; by using in-group identity marker (62 times), using in-group pronoun (59 times), and by informing readers about their research (40 times). This study clearly sees that the strategies and tactics employ by the authors in EG journal has a purposes to bring about solidarity and respect used by EG authors in their articles somehow used to reach the demands of the academic discourse community that expects scientific language to be objective and formal however not losing its intimacy with the economic community members and this is seems in line with the nature of positive politeness strategies.
\end{abstract}

Keywords: politeness, strategy, economic, solidarity, respect.

\section{Introduction}

The study of politeness strategies have become one of the most active areas of research in the area of discourse both in spoken and written. This phenomenon began rises when Goffman published "On face work" in 1955 then followed by Myers in 1989 when he published his article, "The Pragmatics of Politeness in Scientific Articles", and found that the model proposed by Brown and Levinson (1987) could also be applied to interpret the culture of scientific writing.

Since then, many scholars have extended the concept of politeness strategies onto written discourse such as on current research issues (Kasper, 1990), business letters (Maier, 1992), written business discourse (Pilegaard, 1997), scientific texts (Kwok, 1997), persuasion in writings (Cherry, 1988), thesis writing (Faridah Mohd. Noor, 2000), research articles (Dahl, 2008), blogs (Thayalan, 2011), Economic Journals (Hamuddin: 2012).

The present study is interested in studying the positive politeness strategies in economic journals. What makes economics special and selected to be analysed in this study, Holmes (2001), mentioned the economic field is prototypical of the social sciences which combine both science research issues related to human behaviour and science of mathematical 
economic models. Dahl (2009: 2) stressed in his article that economic writing is a combination of "soft" science research issues related to human behaviour and the "hard" science of mathematical economic models. Moreover, this study has chosen to explore economic journals to explore the dominance strategies or the most used tactics of politeness in order to bring about solidarity and respect among authors and readers in economic community.

\section{Politeness Strategy in Economic Articles}

Since the early 1980s, the discussion of various controversial issues in the economics discourse community has led to increasing debate among concerned economists about the ways that they communicate with each other, as well as with non-economists. This debate has been vigorous, and has also influenced the direction and nature of the research into economics discourse by linguists.

Economists' assessments of their own discourse has contributed to a growing awareness by many that the ways they communicate their ideas in economics do not accurately correspond to the ways they actually "do" economics. The debate leads to asserts that economists have two attitudes to their discourse, termed the "official and unofficial, the explicit and implicit." The official explicit attitude (rhetoric) reflects a scientific methodology which is "modernist", that is, a modernism which consists of "an amalgam of logical positivism, behaviourism, operational, and the hypothetic-deductive model of science" (Mc.Closkey: 1986; Gal, 1989; Henderson : 1986; Mauranen:1993; Tadros:1985; Allen \& Pholsward: 1988) and Cameron: 1991).

However, most of the scholars above shared similar view that economists, along with

other academic writers, use linguistic and rhetorical devices in order to persuade readers of their point of view and that there is an intellectual hesitancy to see the use of such devices as acceptable within the conventions of the scientific methods. Therefore this study is in the right track by using the concept of politeness based on Brown and Levinson's classical politeness theory $(1978,1987)$ alongside Myers (1989) and Mulholland's (1994), These theory will enlighten major concept of politeness theory as an arrangement of politeness used by author of EG journal.

\section{METHODOLOGY}

Classical politeness theory proposed by Brown and Levinson (1978) alongside two others studies namely; politeness in scientific articles by Myers (1989) and Mulholland's (1994) compilation of persuasion tactics. These three studies were used dynamically to explain the strategies and tactics found in Economic Growth (EG) journal.

A quick observation on three randomly chosen university libraries and internet search, indicated that there is wide range of economic journals. These cater specifically for specific fields of economy, such as management, human resources, marketing and so forth. However, following two interviews conducted with two senior lecturers (one Associate Professor and one head of department) from the Faculty of Economy, University of Malaya, it was suggested to focus on journals published by economic association. Therefore, this study selected Economic Growth which is published by the American Economic Association.

\section{RESULT}

This section presents the findings based on the analysis of politeness strategies in EG. The analysis explored 78.064 words from 12 articles from time to time (span six years) as the corpus of this study. The data calculated EG authors were explicitly used 4 strategies 
namely, positive politeness, negative politeness, bald-on-record, and off-record politeness strategy. The corpus also recorded that EG authors were totally employed 591 politeness tactics. The table below showed us that positive politeness came out to be the dominance strategy among others with 8 tactics and 285 times being used in EG.

Table 3.1: Choice of Politeness Strategies

\begin{tabular}{|l|l|l|l|}
\hline \multirow{2}{*}{\multicolumn{1}{|c|}{ Politeness Strategies }} & \multicolumn{3}{c|}{ Economic Growth (EG) } \\
\cline { 2 - 4 } & Tactics & Quantities & Percentage(\%) \\
\hline 1. Positive Politeness & 8 & 258 & 53.31 \\
\hline 2. Negative Politeness & 4 & 249 & 51.45 \\
\hline 3. Bald-on Record & 2 & 56 & 11.57 \\
\hline 4. Off-Record & 2 & 28 & 5.78 \\
\hline Total & 16 & 591 & $100 \%$ \\
\hline
\end{tabular}

EG authors were found employ 591 politeness tactics with eight (8) tactics for the purpose of being polite in the writing of economic journals. Even though, these 8 tactics distributed almost in every section of the journal somehow, in introduction, methodology and result seem to be the most favourite sections for the authors to employ the positive politeness as seen in the table 3.2 below.

Table 3.2: Distribution of Positive Politeness Strategies in EG

\begin{tabular}{|c|c|c|c|c|c|c|c|c|c|}
\hline \multirow[b]{2}{*}{; } & \multirow[b]{2}{*}{ TACTICS USED } & \multicolumn{6}{|c|}{ FREQUENCY } & \multirow[b]{2}{*}{ Tone } & \multirow{2}{*}{$\begin{array}{l}\text { Paery } \\
\text { (ik) }\end{array}$} \\
\hline & & $\begin{array}{l}\text { Abstiat } \\
\text { (abs) }\end{array}$ & $\begin{array}{l}\text { [ntrodaction } \\
\text { (nnrv) }\end{array}$ & $\begin{array}{l}\text { Metbol } \\
\text { (weith) }\end{array}$ & $\begin{array}{l}\text { Resuly } \\
\text { (Ire) }\end{array}$ & $\begin{array}{c}\text { Discuseise } \\
\text { (aktc) }\end{array}$ & $\begin{array}{c}\text { Cendurion: } \\
\text { (aradi) }\end{array}$ & & \\
\hline & 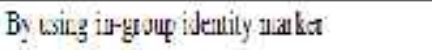 & s & 18 & 1? & 15 & 3 & 2 & 2 & 24.03 \\
\hline & Ber csing in-group proxor. & 2 & 24 & 8 & 11 & 8 & 0 & 29 & 2.30 \\
\hline & Bry irenrirg readers atbut their 1esarch & 4 & 20 & 9 & 7 & 5 & 5 & 40 & 15.50 \\
\hline & Br kering similar view & & 2 & 1: & 11. & 3 & & $3 ?$ & $: 3$ \\
\hline & Br gring 10sins & - & 8 & $\vdots$ & 5 & 2 & 3 & 23 & 89: \\
\hline 6 & Br athuowliging Le coutribulios of olas & - & 14 & 4 & - & 4 & - & 22 & 8.52 \\
\hline & By stowing turnility & - & 5 & - & 2 & 2 & - & 9 & 3.48 \\
\hline 8 & by starng envootal regronse & 0 & 3 & 1 & - & 2 & - & b & 232 \\
\hline \multirow{2}{*}{\multicolumn{2}{|c|}{ TOTAL }} & 11 & 94 & 55 & i1. & 31 & .5 & \multicolumn{2}{|c|}{258} \\
\hline & & 4.25 & 35.7 & 21.3 & 09.76 & 12.01 & 5.22 & \multicolumn{2}{|c|}{$100 \%$} \\
\hline
\end{tabular}


The analysis of the corpus revealed in total of 258 times in EG journal. It consisted of 8 different tactics in this strategy and it seems 3 most used tactics were; by using in-group identity marker (62 times), using in-group pronoun (59 times), and by informing readers about their research (40 times) as seen in the table 3.2 below:

Table 3.2: Positive Politeness Tactics in EG

\begin{tabular}{|c|l|l|l|}
\hline No & \multicolumn{1}{|c|}{ TACTICS } & FREQUENCY & $\begin{array}{c}\text { Percentage } \\
(\%)\end{array}$ \\
\hline 1 & by using in-group identity marker & $\mathbf{6 2}$ & $\mathbf{2 0 . 3 7}$ \\
\hline 2 & by using in-group pronoun & $\mathbf{5 9}$ & $\mathbf{1 9 . 3 4}$ \\
\hline 3 & by informing readers about their research & $\mathbf{4 0}$ & $\mathbf{1 3 . 1 1}$ \\
\hline 4 & by sharing a similar view & 37 & 12.13 \\
\hline 5 & by giving reasons & 23 & 7.54 \\
\hline 6 & by acknowledging the contribution of others & 22 & 7.21 \\
\hline 7 & by showing humility & 9 & 2.95 \\
\hline 8 & by sharing emotional response & 6 & 1.96 \\
\hline & $\quad$ TOTAL & & $\mathbf{2 5 8}$ \\
\hline
\end{tabular}

As seen in Table 4.2, a total of 258 positive politeness tactics were found in the EG corpus. The top three tactics employed are by using in-group identity marker $(20.37 \%)$, followed by using in-group pronoun (19.34\%) and by informing the readers about the research $(13.11 \%)$.

\section{Tactic 1: By using in-group identity markers}

This is the most used tactic by EG's author in this study. It is found that they used this tactic to indicate group membership and to bring about the elements of closeness in order to show solidarity as well as to close the distance between author and readers. This tactics according Brown and Levinson : 1978; Myers : 1989) allowed the authors convey in-group membership and they include in-group usage, address forms of intimate terms, technical terms, jargons or slogan

... thus producing big equivalent ad valorem rate changes, that is, big changes in percentage rate.

(EG-04/01/met. p.8)

(2) Since the inclusions of initials GDP per capita in a dynamic panel can lead to biased coefficients (Nickell, 1981), we also provide a consistent specification that uses lagged GDP per capita as an instrument

(EG-04/01/dis. p.12) 
(3) We are able to construct; the ratio of agricultural prices to the economy-wide labor supply (LANDLAB); the ratio of agricultural land the economy to industrial prices (PAM); the ratio wages rates to farm land rents (WR); total factor productivity in agriculture (TFPG); and labour productivity in manufacturing (INDPROD)

(EG-05/02/meth p.11)

As seen in Examples (1-3), authors used technical terms such as 'ad valorem, GDP per capita, LANDLAB, PAM, TFPG and INDPROD' as a way to inform others, using shared knowledge among the economists. As technical terms are usually understood by people in specific research areas this could be seen as a politeness tactic. This concurs with the work of Mulholland (1994), who state that author can be viewed as being polite when they use technical terms to indicate in-group identity markers.

Tactic 2: By using in-group pronouns

According to Myers (1989), in-group markers such as pronouns are used to show solidarity with scholars, researchers and people in scientific community. In this study, it was found that author use pronoun such as "we, us, our" to express that the writers do not stand alone but as an extended family. The following Example (4) shows the case.

...The conventional approach to these question is driven by what we might call the 'fundamentals' view of the world.

(EG-07/04/intro p.2)

In Example (4) author used the pronoun 'we' that appears to represent 'everyone' in the economics field. The use of the pronoun 'we' appears to show that author are in solidarity and are in the same position with the others, in addition to standing as an extended family. Thus, it was possible for author to mitigate any claims they make in the article.

In the following Examples (5-7), author use the pronoun 'our' and 'we' to represent themselves and their co-researchers:

(5) Our approach has a different micro foundation than either of these, and yields an empirical examination that is much more fine-grained.

(EG-07/04/intro, p.3)

(6) To check the robustness of our findings against these concerns, we have also constructed our measures with the World Trade dataset which....

(EG-07/04/meth, p.11)

(7) This allows us to study the extent to which the VRS model...

(EG-06/03/intro, p.6)

As is seen in Examples (5-6) author used the pronoun 'our' and 'we' that represent themselves and their co-researchers. In addition, in Example (7) author used the pronoun 'us' to also represent the esoteric audiences. This shows that author could mitigate any claim they make in their criticism while minimizing the FTA by including themselves in the criticism. Thus this can be viewed as a politeness tactic that bring about solidarity. 


\section{Tactic 3: By informing readers about their research}

It is found that author used this tactic to inform readers on the possible contributions to economics, the strength of their study and steps taken by the researchers in conducting their studies. In the following Examples (8-9), author informed readers about the possible contributions of their study:

(8) This papers offers explanations based on changing export market growth or transportation cost decline.

(EG-04/01./abs, p.1)

(9) We present in this paper a complementary argument that emphasizes the idiosyncratic elements in specialization patterns. . .

(EG-04/01./intro, p.1)

Examples (8-9) above shows author used phrases such as 'This papers offers explanations' and 'We present in this paper' as a way to inform others of the strengths and possible contribution of the study. This concurs with the work of Myers (1989) and Mulholland (1994), who stated that writers can be viewed as being polite when they inform readers of the strengths, advantages or the possible contributions of their study.

The study found that author also informed readers about the strengths of their research. This could also be viewed as a politeness tactic as revealed in Example (10):

(10) This paper exploits recently-collected data documenting relative factor price trends over the very long run and points out that there was another, equally radical structure break which occurred in north-west Europe. . .

(EG-05/02./intro, p.1)

In Example (10) author informed readers of the strength of the paper as it 'exploits recently-collected data' and 'points out' something which could satisfy the positive face of the readers. The data also revealed that author informed readers of the steps taken in their studies. This can also be viewed as positive politeness as this could satisfy the curiosity of readers of the steps taken in collecting data. In Example (11), author inform readers of the steps taken in their study:

(11) We also include human capital as a regressor, since it plays a role in our theoretical framework. We add the (physical) capital-labor ratio and a rule of law index as well to account for neoclassical explanations for economic growth. Finally, we show both OLS and IV result.

(EG-07/04./meth, p.18)

In this Example (11) author explained the details of their study by informing the steps taken in their study such as 'We also include human capital as a regressor' and 'We add the (physical) capital-labor ratio and a rule of law index ....' This tactic could be seen as a politeness tactic as it allows author to guide readers to the methodology of the study. 


\section{CONCLUSIONS}

This study found that all four strategies of politeness seems have been employ by the EG journal authors in their articles. However, positive politeness seems become the most dominance strategy in were employed the pattern of use reflects the preference of certain politeness strategies over others with the purpose. Quantitative data showed that EG journal authors employed more positive politeness strategies in 8 different tactics. These tactics distributed in almost every section in the article.

Furthermore, this study realized in the use of positive politeness in EG appeared to be intended showing professionalism in their writing without losing the sense of intimacy. Moreover, it is important to note also that positive politeness strategy become more and more effective dominance to use as its nature to create direct and efficient sentences in the journals. This study underlined that every tactics in positive politeness employ to create a friendly atmosphere and to mitigate the impact of imposition in economic journals. Finally, this section leads to highlights the findings that positive politeness leads in terms of frequency and number of tactics used. However, the result of the present study as mention above also showed that there are only small differences in the use and production of positive politeness strategies in Economic Growth (EG) compare to the other three strategies namely Negative politeness, bald-on record as well as off-record politeness strategies therefore every tactics or strategies that can be used to employ to create a friendly atmosphere in journal can be used.

\section{REFERENCES}

[1] Allen, P and R. Pholsward. 1988. The development of a diagnostic reading test for EAP students of economics, in M. L. Tickoo (ed.) ESP: State of the art. Anthology Series 21, SEAMO Regional Language Centre, Singapore, 58-7

[2] Budianto Hamuddin. 2012. A Comparative Study of Politeness Strategies in Economic Journals. Master Thesis. Kuala Lumpur: University Malaya

[3] Brown, P., \& Levinson, S.C. 1978. Universa.ls in language usage: Politeness Phenomena. Cambridge: Cambridge University Press.

[4] Brown, P., \& Levinson, S.C. 1987. Politeness: Some universals in language usage. Cambridge: Cambridge University Press.

[5] Cameron, Maxwell A. 1991. Canada in Latin America. In Fen Osler Hampson \& Christopher J. Maule (Eds.), Canada among nations 1990-91: After the Cold War. pp. 109-123. Ottawa: Carleton University Press.

[5] Cherry, Roger D. 1988. Politeness in Written Persuasion. Journal of Pragmatics, vol.12, pp.63-81.

[6] Dahl, T. 2008. Contributing to the academic conversation: A study of new knowledge claims in economics and linguistics. Journal of Pragmatics, vol.40, pp.1184-1201.

[7] Dahl, T. (2009). The linguistic representation of rhetorical function: A study of how economists present their knowledge claims. Written Communication, 26(4), 370-391.

[8] Faridah Noor.Md.Noor. 2000. Persuasion in Thesis Writing. Unpublished Ph.D Thesis. University of Malaya.

[9] Goffman, Erving.1955. On Face-work: An Analysis of Ritual Elements of Social Interaction. Psychiatry: Journal for the Study of Interpersonal Processes 18(3), 213-231. Reprinted in Goffman (2005, pp. 5-46)

[10] Henderson, W; A. Dudley-Evans and R. Backhouse. (eds.) (1993) Economics and Language. Routledge, London 
[11] Holmes, R. 2001. Variation and text structure: The discussion section in economics research articles. I.T.L. Review of Applied Linguistics, 131-132, 107-137.

[12] Johnstone, B. 2002. Discourse analysis. Oxford: Blackwell.

[13] Kasper, Gabriele. 1990. Linguistic politeness: Current research issues. Journal of Pragmatics 14: 193-218.

[14] Kwok, Kee Wei. 1997. Politeness in scientific text. Hongkong. University of Hongkong Press. Lakoff, Robin. 1973. The Logic of Politeness; or, Minding Your P's. in Papers from the Ninth regional Meeting of the Chicago Linguistic Society, 292-305. Leech, G.N. 1983. Principles of Pragmatics. London: Longman

[15] Maier, Paula. 1992. Politeness Strategies in Business Letters by Native and Non-native English Speakers. English for Specific Purposes, vol.11, pp.189-205.

[16] McCloskey, D. 1986. The Rhetoric of Economics. Brighton: Wheat sheaf Books.

[17] Mullholland, Joan. 1994. Handbook of Persuasive Tactics. A practical language guide. London and New York: Routledge.

[18] Myers, Greg. 1989. The Pragmatics of Politeness in Scientific Articles. Jurnal of Applied Linguistics, vol.10. no. 1. Oxford University Press.

[19] Pilegaard, Morten. 1997. Translation of medical research articles. In Text Typology and Translation, Trosborg, Anna (ed.), 159 ff. Rotenberg, 1991: Winkler and McCuen (1994)

[20] Tadros, A. 1985. Prediction in Text. ELR Monograph, No. 10 Birmingham University.

[21] Thayalan, Xavier. 2011. Social Networking Strategies and Tactics Among Tertiary Students Bloggers. Unpublished Ph.D Thesis. Kuala Lumpur: University Malaya

[22] Watts, Richard J., 2003. Politeness. Cambridge University Press, Cambridge. 
First Author: Budianto Hamuddin, M.Esl is a lecturer from English Department in the Faculty of Education and Teachers Training at the Lancang Kuning University, pekanbaru Indonesia. He was graduated from University of Malaya, Kuala Lumpur at the Faculty of Language and Linguistics.He has published many papers on the area of English Language Teaching (ELT). His interest area covers Discourse Analysis, Semantic, CMC and CALL.

Dahler, M.Pd is a senior lecturer at the English Department as well as the Dean in the Faculty of Education and Teachers Training, Lancang Kuning University, Pekanbaru Indonesia. Currently He was graduated from Padang State University in west Sumatra Indonesia. He has published many papers on the area of English Language Teaching (ELT). His interest area covers Receptive Skill in English, and CAR.

Dr. Jeni Wardi, is an economist as well as private accountant for more than 10 years. $\mathrm{He}$ is also a senior lecturer at the Accountancy department as well at the Faculty of Economic, Lancang Kuning University, Pekanbaru Indonesia. Currently He was also the Director of Community service in the Institute of Research and Commmunity Service UNILAK. He graduated from University of Riau in Indonesia. He has published many papers on the area of Economic and Accountancy. His interest area covers Accountancy, Micro finance, and Public transparency. 
